\title{
Announcement of Business Historical Society Fellowship Awards
}

The President and Fellows of Harvard University, meeting on February 2, 1948, voted to award Fellowships in Business History to Mr. Joe B. Frantz of the University of Texas and to Mr. Vincent P. Carosso of the University of California. Each award carries a stipend of $\$ 2,500$, enabling the recipient to spend twelve months of study and research at the Harvard Graduate School of Business Administration.

These Fellowships are designed to help prepare mature students for teaching American business history. They are being granted this year for the first time and are indications of an increasing recognition that business has played a vital part in shaping American culture. The Business Historical Society sponsored one of the Fellowships; the other was sponsored anonymously.

Both winners of the award will have received their degrees of Doctor of Philosophy before beginning work under the Fellowship arrangement. Mr. Frantz has written his dissertation on the life of Gail Borden, Jr., a pioneer in the condensed milk industry. Mr. Carosso has specialized in the early history of the wine industry in California. Both men are now teaching at their respective universities. They will begin their year of study at the Harvard Business School next September. 